\title{
Synthesis and SAR of the antistaphylococcal natural product nematophin from Xenorhabdus nematophila
}

\author{
Frank Wesche ${ }^{1,2}$, Hélène Adihou ${ }^{1,3,4}$, Thomas A. Wichelhaus ${ }^{5}$ and Helge B. Bode*1,6,§
}

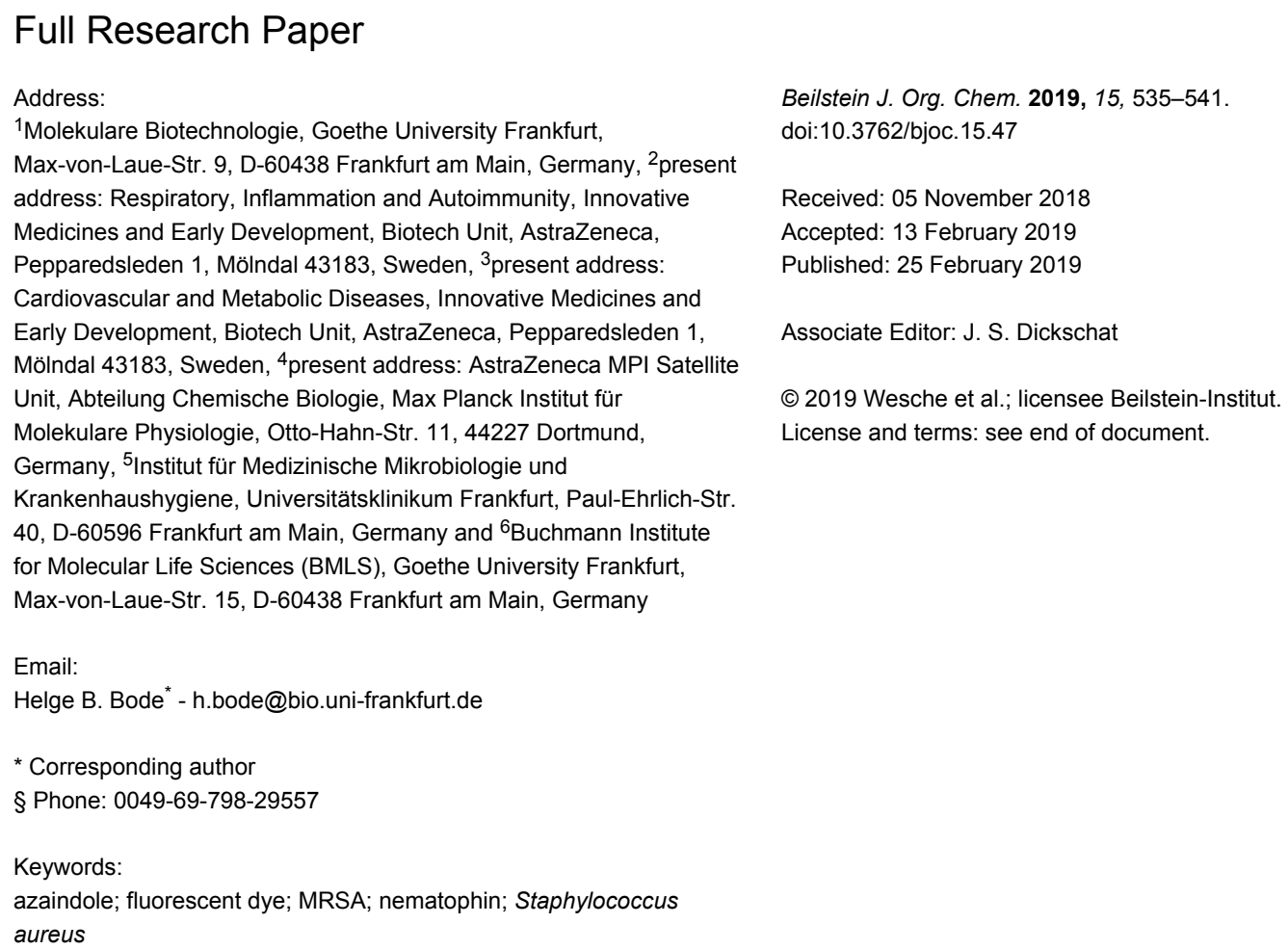

Beilstein J. Org. Chem. 2019, 15, 535-541.

doi:10.3762/bjoc. 15.47

Received: 05 November 2018

Accepted: 13 February 2019

Published: 25 February 2019

Associate Editor: J. S. Dickschat

() 2019 Wesche et al.; licensee Beilstein-Institut.

License and terms: see end of document.

\begin{abstract}
The repeated and improper use of antibiotics had led to an increased number of multiresistant bacteria. Therefore, new lead structures are needed. Here, the synthesis and an expanded structure-activity relationship of the simple and antistaphylococcal amide nematophin from Xenorhabdus nematophila and synthetic derivatives are described. Moreover, the synthesis of intrinsic fluorescent derivatives, incorporating azaindole moieties was achieved for the first time.
\end{abstract}

\section{Introduction}

Microorganisms present a rich source of bioactive natural products of pharmacological importance against an emerging number of multiresistant bacteria [1]. Such examples are Xenorhabdus sp., Gram-negative entomopathogenic bacteria which live in symbiosis with soil-living nematodes of the genera Steinernema [2,3]. During a complex life cycle the nematode-bacteria pair infects and kills insect larvae, whereby Xenorhabdus produce a broad range of natural products with 
antimicrobial properties [4-8]. As the Steinernema-Xenorhabdus complex is not pathogenic against humans, they are widely used as biocontrol agents in agriculture [9].

Natural products produced by bacteria play an important role in the bacteria/nematode/insect life cycle and most natural products are non-ribosomal peptides (NRP), e.g., rhabdopeptides $[10,11]$ and polyketide-NRP hybrids, like xenocoumacins $[12,13]$. The quite simple amide nematophin (1) is another wellknown member of natural products common in all Xenorhabdus nematophila strains and was first described by Li et al. in 1997 for their antimicrobial properties [14]. Simply, $\mathbf{1}$ is the condensation product of 3-methyl-2-oxopentanoic acid and tryptamine and showed good activities against different Gram-positive pathogens like Staphylococcus aureus, including methicillinresistant S. aureus (MRSA) comparable with activities of vancomycin. Recently, the biosynthesis of $\mathbf{1}$ was elucidated by our group as well as the 2-phenylethylamine derivative $\mathbf{2}$ with an $\alpha$-keto amide moiety, which could be identified upon heterologous expression of the appropriate gene cluster in E. coli [15] Moreover, elongated nematophin derivatives, namely nevaltophins from Xenorhabdus PB62.4, were described incorporating an additional valine. As $\mathbf{1}$ and nevaltophines act as prophenoloxidase activators, it is suggested that they have a specific role in the bacteria/nematode/insect symbiosis.

Little or nothing is known about the mode of action of this simple amide against $S$. aureus. Structure-bioactivity studies revealed that the $\alpha$-keto moiety and the amide moiety itself are required for bioactivity [16]. These findings suggest a specific interaction of this electrophilic moiety with a nucleophile. Such an interaction was previously reported for the macrocyclic peptide cyclotheonamide A, isolated from marine sponge Theonella sp. Cyclotheonamide A is described as a potent inhibitor of various proteases, in particular trypsin and thrombin [17-19]. Hereby, the $\alpha$-keto amide covalently binds to the serine oxygen in the active site under formation of a stable tetrahedral hemiketal. Furthermore, substitution of the indole hydrogen by alkyl, aryl or benzyl improves the in vitro antistaphylococcal activity. In contrast, the incorporation of smaller heterocycles like pyridine and imidazole as well as isosteric benzimidazole instead of the indole moieties lead to a loss of antibacterial activity. Kennedy et al. could synthesize a 2-phenyl derivative that showed nanomolar activity against $S$. aureus [20]. To the detriment of this compound class, all derivatives lose their antibacterial activity in the presence of serum in vitro in serial broth and agar dilution method [16,20]. Even with the use of charged groups as modifiers, serum-protein binding could not be avoided. However, we were interested in expanding the aforementioned structure-activity studies regarding the substitution of the indole moiety by different aromatic systems as well as substitution of side chains in the $\alpha$-keto carboxylic acids to generate more derivatives of this fascinating small and bioactive amide.

\section{Results and Discussion}

We first synthesized $\mathbf{1}$ and 1-methylnematophin (3) as standards to confirm preliminary results. We then initiated the synthesis of derivatives 2, and 4-12. Briefly, the appropriate $\alpha$-keto carboxylic acid was coupled to the respective amine. Amide bond formation was achieved using 1-ethyl-3-(3-dimethylaminopropyl)carbodiimide hydrochloride (EDC $\cdot \mathrm{HCl})$, 1-hydroxybenzotriazole (HOBt) and $N, N$-diisopropylethylamine (DIPEA) in DMF under microwave irradiation (Scheme 1). Racemic 1 was synthesized using tryptamine and (rac)-3-methyl-2-oxopentanoic acid. Similarly, compounds 2-7 were synthesized using different amines including 2-phenylethylamine (for 2), 1-methyltryptamine (for 3), 2-(2naphthyl)ethylamine hydrochloride (for 4), 2-(1-naphthyl)ethylamine hydrochloride (for 5), 2-(1H-inden-3-yl)ethylamine hydrobromide (for 6) [21], and 2-(1-benzofuran-3-yl)ethylamine (for 7), respectively. Compounds 8-12 were synthesized by coupling tryptamine with different $\alpha$-keto carboxylic acids, including 3-furylglyoxylic acid (for 8), 3-indoleglyoxylic acid (for 9), phenylglyoxylic acid (for 10), and isomeric 3-methylpent-2-enoic acid (for 11 and 12) [22], respectively. Compounds 11 and 12 were separated during the isolation process and initially constructed to enable target identification. Compounds 11 and 12 might act as Michael acceptor $(\alpha, \beta$ unsaturated carbonyl) and attach irreversibly and covalently to a potential target [23]. After purification and characterization, the above mentioned compounds were tested against different pathogenic strains, i.e., methicillin-susceptible $S$. aureus (MSSA), methicillin-resistant S. aureus (MRSA), Enterococcus faecalis, and Micrococcus luteus. The yields and bioactivities are summarized in Table 1 (and Table S1, Supporting Information File 1).

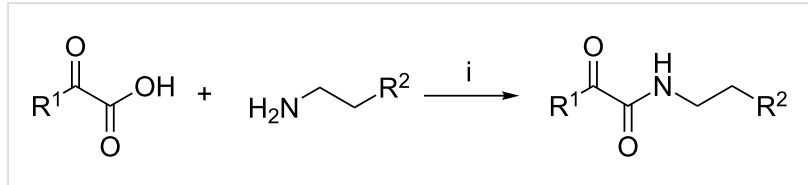

Scheme 1: General procedure for the synthesis of nematophin and related derivatives. i) 1.5 equiv a-keto carboxylic acid, 1.0 equiv amine, 1.5 equiv $\mathrm{EDC} \cdot \mathrm{HCl}, 1.5$ equiv $\mathrm{HOBt}, 2.0$ equiv DIPEA in DMF (c $0.1 \mathrm{M}), 25 \mathrm{~W}, 75^{\circ} \mathrm{C}, 20 \mathrm{~min}$.

As previously described, the minimum inhibitory concentration (MIC) of $\mathbf{1}$ improves by alkylation of the indole moiety as seen for $\mathbf{3}$ [16] even $\mathbf{1}$ and $\mathbf{3}$ show a good activity against MRSA. Although for all other tested compounds no better activity than that of the original natural product $\mathbf{1}$ was observed, $\mathbf{6}$ showed an 
Table 1: Summary of synthesized nematophin derivatives (1-12) and their bioactivity (MIC in $\mu \mathrm{g} / \mathrm{mL}$ ) against $S$. aureus (MSSA and MRSA)

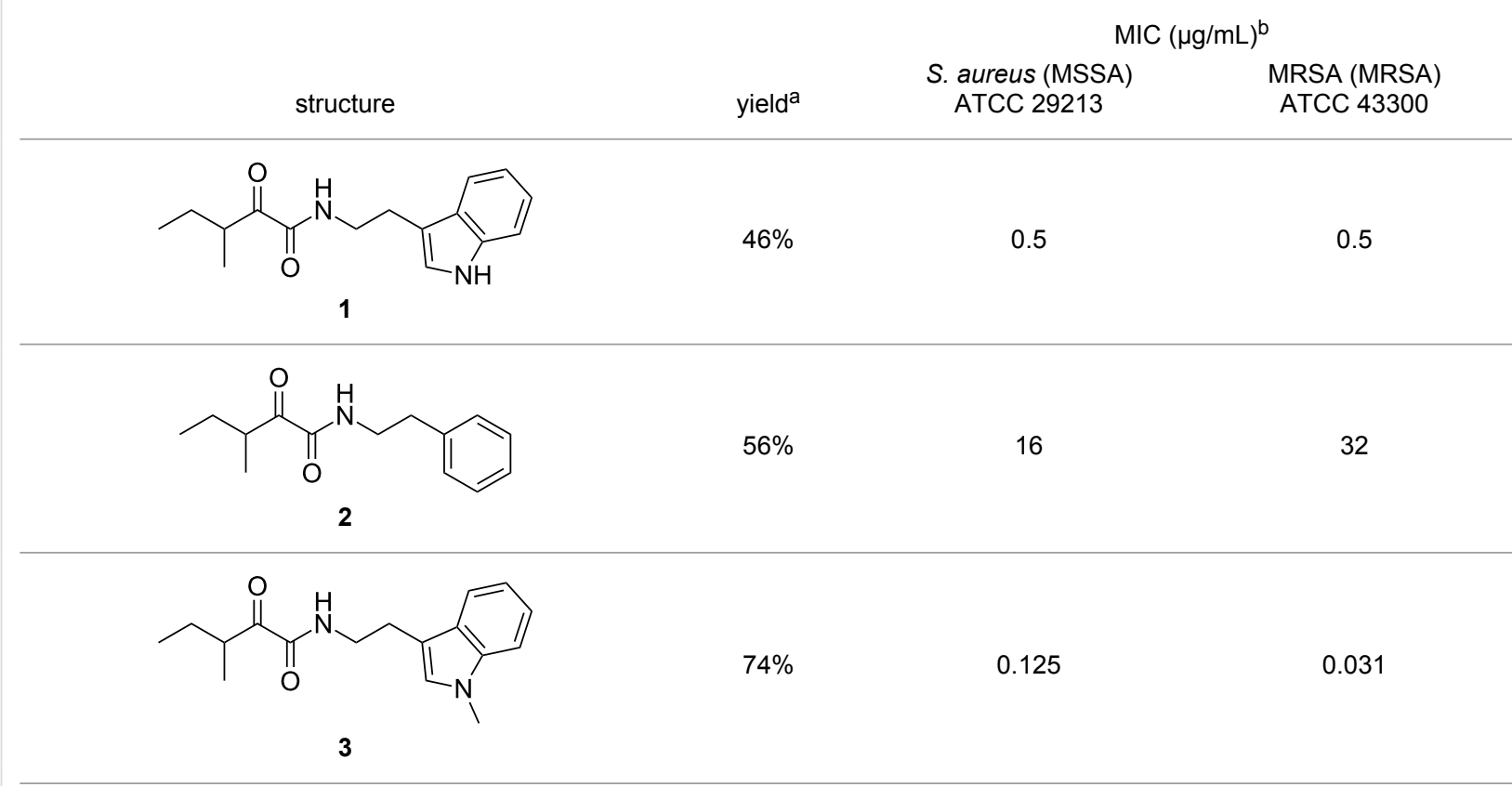

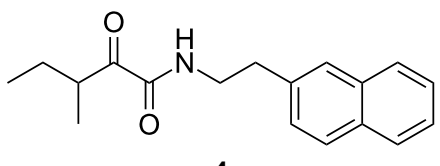<smiles>CCC(C)C(=O)C(=O)NCCc1cccc2ccccc12</smiles>

5<smiles>CCC(C)C(=O)C(=O)NCCC1=CCc2ccccc21</smiles>

6<smiles>CCC(C)C(=O)C(=O)NCCc1coc2ccccc12</smiles>

7<smiles>[R]OCCc1c[nH]c2ccccc12</smiles>

8<smiles>O=C(NCCc1c[nH]c2ccccc12)C(=O)c1c[nH]c2ccccc12</smiles>

$84 \%$

$>128$

$59 \%$

$>64$

$>64$ 
Table 1: Summary of synthesized nematophin derivatives (1-12) and their bioactivity (MIC in $\mu \mathrm{g} / \mathrm{mL})$ against $S$. aureus (MSSA and MRSA). (continued)<smiles>O=C(NCCc1c[nH]c2ccccc12)C(=O)c1ccccc1</smiles>

10
$47 \%$

$59 \%^{\mathrm{c}}$

$59 \%^{\mathrm{c}}$
8

$>128$

$>128$

11<smiles>CC/C(C)=C/C(=O)NCCc1c[nH]c2ccccc12</smiles>

aPurification using column chromatography on silica gel. ${ }^{\mathrm{b}}$ Median of three experiments. ${ }^{\mathrm{C}}$ Derivatives were synthesized using an isomeric mixture of 3-methylpent-2-enoic acid.

activity comparable to $\mathbf{1}$ against MRSA. Since only a slight activity could be observed for some compounds against additionally tested bacteria, i.e., M. luteus ATCC 9431 and E. faecalis ATCC 29212, a staphylococcal-specific target is suggested. All derivatives with $\alpha$-keto- $\beta$-methylvaleric moiety (1-7) were active against $S$. aureus. Substitution of the side chain in the $\alpha$-keto amide significantly affects the bioactivity, as seen for compounds $\mathbf{8 , 9}$ and $\mathbf{1 0}$. Furthermore, attempts to identify a possible target by the incorporation of an $\alpha, \beta$-unsaturated carbonyl moiety, as it should bind irreversible to a potential target, instead of the $\alpha$-keto amide in $\mathbf{1 1}$ and $\mathbf{1 2}$ are stalled as it led to a complete loss of bioactivity.

To the best of our knowledge, no one has ever tried to incorporate azaindole moieties in small natural products and tried to use them for fluorescence imaging. This approach may circumvent the above-mentioned impasse and should allow at least localization studies in S. aureus cells. Azaindoles are isosteric to indole, whereas one of the endocyclic methines is substituted with nitrogen, and thus leads to an increased and red-shifted fluorescence [24-26]. Budisa and co-workers have already used azatryptophans to study proteins with intrinsic green and blue fluorescence $[27,28]$. The azaindole moiety allows a linker-less incorporation of a fluorescent label with minimal disturbance.

Therefore, four fluorescent derivatives of nematophin were designed and their synthesis initiated. The syntheses of the appropriate azatryptamine derivatives $(\mathbf{1 7}, \mathbf{1 8}, \mathbf{2 5}$, and $\mathbf{2 6})$ were achieved from the non-expensive and commercially available 4and 7-azaindole (13 and 20), respectively. First, $\mathbf{1 3}$ and $\mathbf{2 0}$ were converted in a Friedel-Crafts acylation with chloroacetyl chloride $\left(\mathrm{ClCH}_{2} \mathrm{COCl}\right)$ and aluminium chloride $\left(\mathrm{AlCl}_{3}\right)$ in DCM to give compounds $\mathbf{1 4}$ and 21. Subsequent reduction was achieved with triethylsilane $\left(\mathrm{Et}_{3} \mathrm{SiH}\right)$ in TFA to give $\mathbf{1 5}$ and 22. For the synthesis of the primary amine, halides $\mathbf{1 5}$ and $\mathbf{2 2}$ were converted in a Gabriel synthesis with potassium phthalimide in DMF to the appropriate phthalimides 16 and 23 [29]. These intermediary compounds $\mathbf{1 6}$ and $\mathbf{2 3}$ also allowed an $N$-methylation of the azaindole moiety with sodium hydride $(\mathrm{NaH})$ and methyl iodide (MeI) to yield $\mathbf{1 7}$ and 24. By ethanolic hydrazinolysis and microwave irradiation the phthalimides $(\mathbf{1 6}, \mathbf{1 7}, \mathbf{2 3}$, and 24) were deprotected yielding the desired primary amines in good yields (18, 19, 25, and 26) (Scheme 2 and Scheme 3). With all building blocks available, the synthesis of the appropriate fluorescent derivatives was performed as before, using (rac)-3-methyl-2-oxopentanoic acid. Yields after coupling and bioactivities are summarized in Table 2 .

Whereas the biological data, for example against $S$. aureus or MRSA shows a decreased activity for all azaindole derivatives (compare $\mathbf{1}$ with $\mathbf{2 7}$ or $\mathbf{2 8}$ ) as observed for isosteric benzimidazoles [20], an increased activity for all methylated derivatives (compare pairs of $\mathbf{1 / 3}, \mathbf{2 7 / 2 8}$, and $\mathbf{2 9 / 3 0}$ ) could be observed for at least MSSA. This observation may correlate to the molecular polarity, and thus hydrophilicity of the cyclic moiety, whereas almost all hydrophobic moieties showed good antistaphylococcal activity as seen for naphthyl (4 and 5) and indene (6). However, the increase of hydrophobicity influences the passive membrane diffusion and therefore might influence how the compounds get to their actual target [30]. Moreover, a specific 
<smiles>c1cnc2cc[nH]c2c1</smiles>

4-azaindole (4AI)

(13)

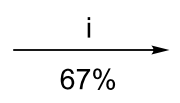$$
\text { ) }
$$$$
14
$$

14<smiles>C[13CH2]C(C)C</smiles>

4<smiles>Cn1cc(CCN2C(=O)c3ccccc3C2=O)c2ncccc21</smiles>

17<smiles>Cn1cc(CCN)c2ncccc21</smiles>

1M4ATRA (19)

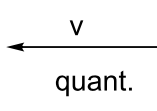

)

(1)<smiles>ClCCc1c[nH]c2cccnc12</smiles>

15

iii<smiles>c1cnc2[nH]ccc2c1</smiles><smiles>CC(C)(C)C</smiles>

7-azaindole (7AI)

(20)<smiles>Cn1cc(CCN)c2cccnc21</smiles>

1M7ATRA (26)<smiles>Cc1c[nH]c2ncccc12</smiles>

21<smiles>Cn1cc(CCN2C(=O)c3ccccc3C2=O)c2cccnc21</smiles>

24<smiles>ClCCc1c[nH]c2ncccc12</smiles>

Scheme 3: Synthesis of azatryptamines (7-azatryptamine (7ATRA) and 1-methyl-7-azatryptamine (1M7ATRA)). i) 5.0 equiv AICl $3,5.0$ equiv $\mathrm{ClCH}_{2} \mathrm{COCl}$ in DCM, overnight, rt $32 \%$; ii) 7.0 equiv $\mathrm{Et}_{3} \mathrm{SiH}$ in TFA, overnight, rt, $93 \%$; iii) 1.1 equiv potassium phthalimide, in DMF, $100{ }^{\circ} \mathrm{C}, 56 \%$; iv) 1.2 equiv $\mathrm{NaH}, 1.0$ equiv Mel in DMF, overnight, rt, $57 \%$; v) 5.0 equiv $\mathrm{N}_{2} \mathrm{H}_{4} \cdot \mathrm{H}_{2} \mathrm{O}$ in $\mathrm{EtOH}, 2 \mathrm{~h}, 90{ }^{\circ} \mathrm{C}, 25 \mathrm{~W}, 92 \%$ to quant.

minimal size of the cyclic moiety must be fulfilled as, e.g., 2 with a phenyl moiety is less active in vitro.

\section{Conclusion}

Despite their lower bioactivities, the azaindole derivatives are currently under investigation upon their use for fluorescence imaging. Furthermore, derivatives $\mathbf{3}$ and $\mathbf{6}$ will be further studied for identification of their actual target in $S$. aureus. This could be a serine protease that can also be addressed in the future by more stable compounds. Moreover, it might be possible to use nematophin and its derivatives for topical treatment of $S$. aureus infections. 
Table 2: Summary of synthesized nematophin derivatives (27-30) and their bioactivity (MIC in $\mu \mathrm{g} / \mathrm{mL})$ against $S$. aureus (MSSA and MRSA).

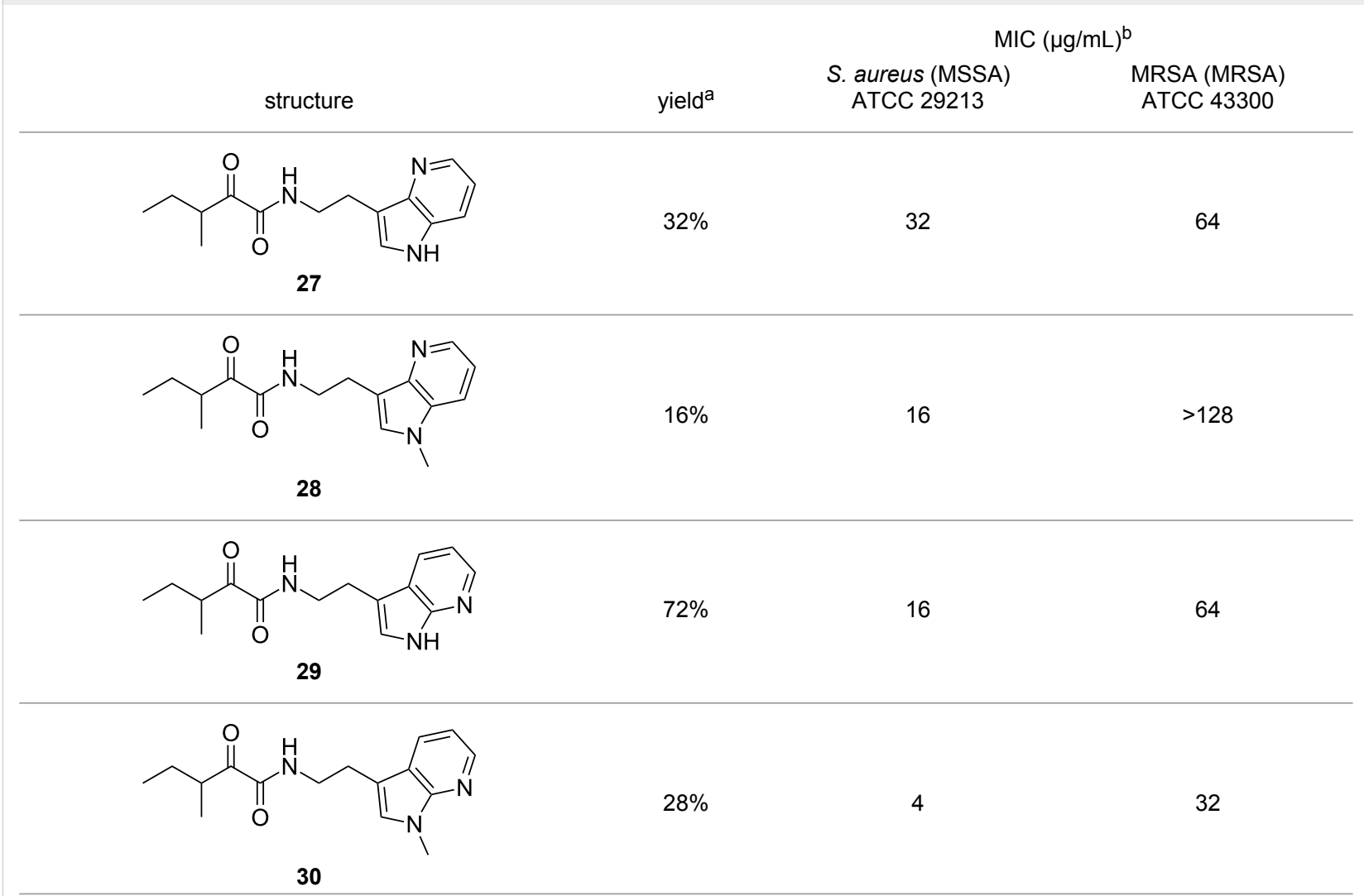

apurification using column chromatography on silica gel. ${ }^{\text {bMedian }}$ of three experiments.

\section{Supporting Information}

\section{Supporting Information File 1}

General procedure, supplemantary table and NMR spectra. [https://www.beilstein-journals.org/bjoc/content/ supplementary/1860-5397-15-47-S1.pdf]

\section{Acknowledgements}

We thank Denia Frank for excellent technical support. This work was supported by the LOEWE program of the state of Hesse as part of the MegaSyn research cluster to H.B.B.

\section{ORCID ${ }^{\circledR}$ iDs}

Frank Wesche - https://orcid.org/0000-0001-6340-3155 Helge B. Bode - https://orcid.org/0000-0001-6048-5909

\section{References}

1. Li, J. W.-H.; Vederas, J. C. Science 2009, 325, 161-165. doi:10.1126/science.1168243

2. Herbert, E. E.; Goodrich-Blair, H. Nat. Rev. Microbiol. 2007, 5, 634-646. doi:10.1038/nrmicro1706
3. Goodrich-Blair, H.; Clarke, D. J. Mol. Microbiol. 2007, 64, 260-268. doi:10.1111/j.1365-2958.2007.05671.x

4. Shi, Y.-M.; Bode, H. B. Nat. Prod. Rep. 2018, 35, 309-335. doi:10.1039/c7np00054e

5. Vizcaino, M. I.; Guo, X.; Crawford, J. M. J. Ind. Microbiol. Biotechnol. 2014, 41, 285-299. doi:10.1007/s10295-013-1356-5

6. Klassen, J. L. Curr. Opin. Insect Sci. 2014, 4, 15-22. doi:10.1016/j.cois.2014.08.004

7. Challinor, V. L.; Bode, H. B. Ann. N. Y. Acad. Sci. 2015, 1354, 82-97. doi:10.1111/nyas.12954

8. Crawford, J. M.; Portmann, C.; Zhang, X.; Roeffaers, M. B. J.; Clardy, J. Proc. Natl. Acad. Sci. U. S. A. 2012, 109, 10821-10826. doi:10.1073/pnas.1201160109

9. Shapiro-llan, D. I.; Gouge, D. H.; Koppenhöfer, A. M. Factors affecting commercial success: case studies in cotton, turf and citrus.. In Entomopathogenic nematology; Gaugler, R., Ed.; CABI: Wallingford, 2002; pp 333-355. doi:10.1079/9780851995670.0333

10. Cai, X.; Nowak, S.; Wesche, F.; Bischoff, I.; Kaiser, M.; Fürst, R.; Bode, H. B. Nat. Chem. 2017, 9, 379-386. doi:10.1038/nchem.2671

11. Reimer, D.; Cowles, K. N.; Proschak, A.; Nollmann, F. I.; Dowling, A. J.; Kaiser, M.; ffrench-Constant, R.; Goodrich-Blair, H.; Bode, H. B. ChemBioChem 2013, 14, 1991-1997. doi:10.1002/cbic.201300205

12. Reimer, D.; Luxenburger, E.; Brachmann, A. O.; Bode, H. B. ChemBioChem 2009, 10, 1997-2001. doi:10.1002/cbic.200900187 
13. Mclnerney, B. V.; Taylor, W. C.; Lacey, M. J.; Akhurst, R. J.; Gregson, R. P. J. Nat. Prod. 1991, 54, 785-795. doi:10.1021/np50075a006

14. Li, J.; Chen, G.; Webster, J. M. Can. J. Microbiol. 1997, 43, 770-773. doi:10.1139/m97-110

15. Cai, X.; Challinor, V. L.; Zhao, L.; Reimer, D.; Adihou, H.; Grün, P.; Kaiser, M.; Bode, H. B. Org. Lett. 2017, 19, 806-809. doi:10.1021/acs.orglett.6b03796

16. Himmler, T.; Pirro, F.; Schmeer, N. Bioorg. Med. Chem. Lett. 1998, 8, 2045-2050. doi:10.1016/s0960-894x(98)00358-8

17. Lee, A. Y.; Hagihara, M.; Karmacharya, R.; Albers, M. W.; Schreiber, S. L.; Clardy, J. J. Am. Chem. Soc. 1993, 115, 12619-12620. doi:10.1021/ja00079a065

18. Maryanoff, B. E.; Qiu, X.; Padmanabhan, K. P.; Tulinsky, A.; Almond, H. R.; Andrade-Gordon, P.; Greco, M. N.; Kauffman, J. A.; Nicolaou, K. C.; Liu, A. Proc. Natl. Acad. Sci. U. S. A. 1993, 90 , 8048-8052. doi:10.1073/pnas.90.17.8048

19. Fusetani, N.; Matsunaga, S.; Matsumoto, H.; Takebayashi, Y. J. Am. Chem. Soc. 1990, 112, 7053-7054. doi:10.1021/ja00175a045

20. Kennedy, G.; Viziano, M.; Winders, J. A.; Cavallini, P.; Gevi, M.; Micheli, F.; Rodegher, P.; Seneci, P.; Zumerle, A.

Bioorg. Med. Chem. Lett. 2000, 10, 1751-1754. doi:10.1016/s0960-894x(00)00331-0

21. Liu, S.; Motta, A.; Delferro, M.; Marks, T. J. J. Am. Chem. Soc. 2013, 135, 8830-8833. doi:10.1021/ja4039505

22. Tiseni, P. S.; Peters, R. Chem. - Eur. J. 2010, 16, 2503-2517. doi:10.1002/chem.200902896

23. Gersch, M.; Kreuzer, J.; Sieber, S. A. Nat. Prod. Rep. 2012, 29 , 659-682. doi:10.1039/c2np20012k

24. Chen, Y.; Rich, R. L.; Gai, F.; Petrich, J. W. J. Phys. Chem. 1993, 97 , 1770-1780. doi:10.1021/j100111a011

25. Cash, M. T.; Schreiner, P. R.; Phillips, R. S. Org. Biomol. Chem. 2005, 3, 3701-3706. doi:10.1039/b506652b

26. Carnerero, J. M.; González-Benjumea, A.; Carmona, C.; Balón, M. Spectrochim. Acta, Part A 2012, 97, 1072-1078. doi:10.1016/j.saa.2012.07.099

27. Lepthien, S.; Hoesl, M. G.; Merkel, L.; Budisa, N. Proc. Natl. Acad. Sci. U. S. A. 2008, 105, 16095-16100. doi:10.1073/pnas.0802804105

28. Hoesl, M. G.; Larregola, M.; Cui, H.; Budisa, N. J. Pept. Sci. 2010, 16, 589-595. doi:10.1002/psc.1263

29. Osby, J. O.; Martin, M. G.; Ganem, B. Tetrahedron Lett. 1984, 25 , 2093-2096. doi:10.1016/s0040-4039(01)81169-2

30. Veber, D. F.; Johnson, S. R.; Cheng, H.-Y.; Smith, B. R.; Ward, K. W.; Kopple, K. D. J. Med. Chem. 2002, 45, 2615-2623. doi:10.1021/jm020017n

\section{License and Terms}

This is an Open Access article under the terms of the Creative Commons Attribution License

(http://creativecommons.org/licenses/by/4.0). Please note that the reuse, redistribution and reproduction in particular requires that the authors and source are credited.

The license is subject to the Beilstein Journal of Organic Chemistry terms and conditions:

(https://www.beilstein-journals.org/bjoc)

The definitive version of this article is the electronic one which can be found at:

doi:10.3762/bjoc. 15.47 